\title{
Mycoplasma and Eperythrozoon (Mycoplasmataceae). Comments on a recent paper
}

In papers on the taxonomy of a number of species of haemoparasitic bacteria of the genera Eperythrozoon and Haemobartonella, Neimark et al. $(2001,2002,2004)$ (and others such as Messick et al., 2002) formally proposed the transfer of these species from the order Rickettsiales to the order Mycoplasmatales, family Mycoplasmataceae. This supported the earlier studies of Neimark \& Kocan (1997) and Rikihisa et al. (1997). The proposal was based mainly on comparisons of 16S rRNA gene sequences. The evidence for the transfer of these bacteria to the Mycoplasmatales is convincing. However, we do not think that the molecular evidence presented justifies the fusion of the genera Eperythrozoon and Haemobartonella with the genus Mycoplasma, as we discussed in a recent paper (Uilenberg et al., 2004). Indeed, not only are the gene sequences that were compared only a very small portion of the genome, but the percentage similarity between 16S rRNA gene sequences of Eperythrozoon wenyonii and one of its closest relatives, Mycoplasma fastidiosum, is relatively low at only about $77 \%$, well below the level expected for micro-organisms belonging to the same genus (Uilenberg et al., 2004). In their 1997 paper, Neimark and Kocan had already found a similarly low relationship between E. wenyonii and the Mycoplasma pneumoniae group (Neimark \& Kocan, 1997). Moreover, there are other differences between members of the genera Eperythrozoon and (classical) Mycoplasma, such as habitat and probably their mode of transmission (although for most of the members of the genus

Eperythrozoon, it is still not known how they are transmitted).

In a recent study, Neimark et al. (2005) showed that in a phylogenetic tree based on $16 \mathrm{~S}$ rRNA gene sequences, the type species of the genus Eperythrozoon, Eperythrozoon

Published online ahead of print on 11 November 2005 as DOI 10.1099/ijs.0.63998-0. coccoides, is also close to the Eperythrozoon (and Haemobartonella) species that were transferred earlier to the genus Mycoplasma. The 16S rRNA gene sequence similarity of E. coccoides and its closest relative of the (classical) Mycoplasma species, $M$. fastidiosum, is only $80 \cdot 2 \%$, which is slightly higher than that of E. wenyonii, but nevertheless means that the type species of Eperythrozoon is not sufficiently close to the (classical) Mycoplasma species to justify the fusion of the genera Eperythrozoon and Mycoplasma. In addition, we have aligned the 16S rRNA gene sequences (published on the NCBI website) of another species of 'classical' Mycoplasma, Mycoplasma mycoides subsp. mycoides SC (small colonies) (MmmSC, causal agent of contagious bovine pleuropneumonia), with those of E. coccoides as well as those of a member of the Mycoplasmataceae belonging to another genus, Ureaplasma parvum serovar 3, strain ATCC 700970 (GenBank accession no. NC_002162). Based on 16S rRNA gene sequences, the similarity of MmmSC and E. coccoides is even less than that between MmmSC and U. parvum, $72 \cdot 1$ and $78 \cdot 1 \%$, respectively. Furthermore, we have found, using this same criterion, that the similarity of MmmSC and a species of a different family and even a different order of the class Mollicutes, Spiroplasma citri (family Spiroplasmataceae, order Entomoplasmatales) is greater than that between MmmSC and E. coccoides, at 87 and $72 \cdot 1 \%$, respectively.

Finally, we have also aligned the $16 \mathrm{~S}$ rRNA gene sequences of MmmSC and a phytoplasma, Onion yellow phytoplasma OY-M (GenBank accession no.

NC_005303); their similarity (using solely this criterion) is also closer than that of MmmSC and E. coccoides, $78 \cdot 9$ and $72 \cdot 1 \%$. In fact, the logical consequences of the proposals of Neimark and co-workers would be the abolition of the family Spiroplasmataceae and the order Entomoplasmatales and the transfer of
Ureaplasma, Spiroplasma and phytoplasma to the genus Mycoplasma, rather than the transfer of the genus Eperythrozoon to the genus Mycoplasma!

It is evident that taxonomy based solely on comparing 16S rRNA gene sequences is insufficient. It is also clear that Eperythrozoon and Mycoplasma should be considered as different taxa, even if only on the basis of such a comparison. It has not even been shown that the genus Eperythrozoon belongs in the same family as the genus Mycoplasma. A direct consequence of the taxonomic opinion expressed in this letter is that the validly published names Eperythrozoon and Mycoplasma may continue to be used as separate genera, within the class Mollicutes, possibly in one and the same family, the Mycoplasmataceae.

Another point is that of priority. The genus name Eperythrozoon, created in 1928, has priority over Mycoplasma, published in 1929. As the study reported by Neimark et al. (2001) did not include the type species of Eperythrozoon, E. coccoides, the question of priority did not have to be addressed. Following the publication of their 2005 paper (Neimark et al., 2005), which includes the type species, this question cannot now be avoided. If the proposal for the fusion of the genera Eperythrozoon and Mycoplasma were to be taken seriously, all members of the genus Mycoplasma should be renamed Eperythrozoon and not the other way around. Neimark et al. (2005) request that the priority of Eperythrozoon over Mycoplasma be waived, in order to avoid confusion. Quoting our 2004 paper (Uilenberg et al., 2004), Neimark et al. (2005) state that we proposed that all Mycoplasma species should be renamed Eperythrozoon. What we really said in that publication is that, if it were to be shown that E. coccoides also belongs to the mycoplasmas (as is now the case), the transfer of the genus Eperythrozoon to the genus Mycoplasma (with which we do not 
agree, as stated very clearly in our paper), would create problems of priority (in addition to not being justified).

\section{Acknowledgements}

We wish to thank Professor J. P. Euzéby of the Ecole Nationale Vétérinaire in Toulouse for his valuable comments and advice.

\section{Gerrit Uilenberg, ${ }^{1,2} \dagger$ François Thiaucourt ${ }^{1}$ and Frans Jongejan ${ }^{2,3}$}

${ }^{1}$ CIRAD-EMVT, Campus International de Baillarguet, 34398 Montpellier Cedex 5, France

${ }^{2}$ Department of Parasitology and Tropical Veterinary Medicine, Faculty of Veterinary Medicine, Utrecht University, PO Box 80.165, 3508 TD Utrecht, The Netherlands

${ }^{3}$ Department of Veterinary Tropical Diseases, Faculty of Veterinary Science, University of Pretoria, Private Bag X04, Onderstepoort 110, South Africa
†Present address: 'A Surgente', route du Port, 20130 Cargèse (Corsica), France

Correspondence: Gerrit Uilenberg (uilenber@club-internet.fr)

Messick, J. B., Walker, P. G., Raphael, W., Berent, L. \& Shi, X. (2002). 'Candidatus Mycoplasma haemodidelphidis' sp. nov., 'Candidatus Mycoplasma haemolamae' sp. nov. and Mycoplasma haemocanis comb. nov., haemotrophic parasites from a naturally infected opossum (Didelphis virginiana), alpaca (Lama pacos) and dog (Canis familiaris): phylogenetic and secondary structural relatedness of their 16S rRNA genes to other mycoplasmas. Int J Syst Evol Microbiol 52, 693-698.

Neimark, H. \& Kocan, K. M. (1997). The cell wall-less rickettsia Eperythrozoon wenyonii is a Mycoplasma. FEMS Microbiol Lett 156, 287-291.

Neimark, H., Johansson, K. E., Rikihisa, Y. \& Tully, J. G. (2001). Proposal to transfer some members of the genera Haemobartonella and Eperythrozoon to the genus Mycoplasma with descriptions of 'Candidatus Mycoplasma haemofelis', 'Candidatus Mycoplasma haemomuris', 'Candidatus Mycoplasma haemosuis' and 'Candidatus Mycoplasma wenyonii'. Int J Syst Evol Microbiol 51, 891-899.

Neimark, H., Johansson, K. E., Rikihisa, Y. \&

Tully, J. G. (2002). Revision of haemotrophic Mycoplasma species names. Int J Syst Evol Microbiol 52, 683.

Neimark, H., Hoff, B. \& Ganter, M. (2004). Mycoplasma ovis comb. nov. (formerly Eperythrozoon ovis), an epierythrocytic agent of haemolytic anaemia in sheep and goats. Int J Syst Evol Microbiol 54, 365-371.

Neimark, H., Peters, W., Robinson, B. L. \& Stewart, L. B. (2005). Phylogenetic analysis and description of Eperythrozoon coccoides, proposal to transfer to the genus Mycoplasma as Mycoplasma coccoides comb. nov. and Request for an Opinion. Int J Syst Evol Microbiol 55, 1385-1391.

Rikihisa, Y., Kawahara, M., Wen, B., Kociba, G., Fuerst, P., Kawamori, F., Suto, C., Shibata, S. \& Futohashi, M. (1997). Western immunoblot analysis of Haemobartonella muris and comparison of 16S rRNA gene sequences of H. muris, H. felis and Eperythrozoon suis. J Clin Microbiol 35, 823-829.

Uilenberg, G., Thiaucourt, F. \& Jongejan, F. (2004). On molecular taxonomy: what is in a name? Exp Appl Acarol 32, 301-312. 